\title{
STUDY THE SHORT TERM CHRONIC TOXICITY OF CYCLOSPORINE EXPOSURE ON TESTIS, HEART AND LUNGS AND THE POSSIBLE PROTECTIVE EFFECTS OF L- ARGININE IN ADULT ALBINO RATS
}

\author{
Eman Ahmad Alaa-Eldin and Nehal S. Abouhashem * \\ Departments of Forensic Medicine \& Clinical Toxicology and Pathology * \\ Faculty of Medicine, Zagazig University, Egypt
}

\begin{abstract}
Objective: Cyclosporine A (CsA) is an immunosuppressive drug widely used after organ transplantation or in treatment of auto-immune diseases. However, several side effects are commonly associated with CsA long term intake. The Aim of the present study was to evaluate the sub-chronic toxicity ( 8 weeks) of CsA on testis, heart and lungs in adult male albino rats, and to determine the potential protective effect of amino acid L-arginine. Material and Methods: A total of 48 adult male albino rats divided into in to 4 groups. Group I (control group) which is subdivided into 3 groups each of 8 rats: Group I.a- negative control group each rat received only regular diet and water. Group I.b- positive control group: each rat received olive oil (0.5 cc) emulsion daily by oral gavage. Group I.c- positive control group: each rat received distilled water $(0.5 \mathrm{cc})$ daily by oral gavage. Group II. Cyclosporine CsA group: (8 rats) each rat received Cyclosporine CsA $74 \mathrm{mg} / \mathrm{kg}$ (1120 of LD50) in an olive oil emulsion $(0.5 \mathrm{cc})$ daily by oral gavage .Group III. L-Arginine group: (8 rats) each rat received L-Arginine $300 \mathrm{mg} / \mathrm{kg}$ daily by oral gavage .Group IV. Cyclosporine CsA plus L-Arginine group: (8 rats) each rat received $300 \mathrm{mg} / \mathrm{kg} / \mathrm{day}$ of L- Arginine by oral gavage a week before CsA treatment was initiated. The rats then received Cyclosporine CsA (74mg/kg in an olive oil emulsion) by oral gavage for 8 weeks. After the end of the study, blood samples were taken to measure serum testosterone levels. Testis, heart, and lungs were removed and subjected to histopathological study. Results: In CsA treated (group II), there was a significant decrease in the serum testosterone levels. Histopathological changes were in the form of (testis showed extensive degeneration of seminiferous tubules, necrosis and interstitial edema), (heart showed extensive connective tissue formation among myocardial fibers with disorganization of myocardial fibers confirmed by Masson's Trichrome Stained sections revealing extensive fibrosis) and (lungs showed large area of acute bronchopneumonia, many alveolar walls are covered by fibrin exudates and inflammatory cellular infiltrate). While Cyclosporine CsA plus L-Arginine group (group IV) revealed partial improvement in the previous histopathological changes. The heart, showed mild myocardial disorganization and sparse connective tissue among myocardial fibers. The lung showed edematous thickening of the alveolar walls and sparse inflammatory cellular infiltrate and the testis showed that most of seminiferous tubules retain its normal structure, few show degeneration and necrosis. Conclusion: From the previous results, it can be concluded that CsA induced toxic effects in the testis as evidenced by biochemical and histopathological changes. Also,
\end{abstract}


Heart and lungs showed histopathological damage. Pre-treatment with L-Arginine group (IV) reduced the subsequent CsA injury in testis, heart and lungs.

Keywords: L-Arginine ; Cyclosporine; testis; heart; lung

\section{INTRODUCTION}

Organ rejection is a result of cellular immunologic reaction that can be avoided by introduction of immunosuppressive medications. The immunosuppressive treatment blocks all immune responses to bacteria, fungi, even malignant tumours (Ishida et al., 2007).

With the use of more powerful and widely used immunosuppressive drugs such as cyclosporine, Survival rates in patients receiving solid-organ transplantation such as the kidney, heart, or liver have improved significantly due to effective control of acute rejection episodes among patients (Rubert et al., 2015; Heo et al., 2016).

Cyclosporin A (CsA), which is a neutral, hydrophobic and cyclic peptide composed of 11 amino acid residues, was originally obtained from the fungi Cylindrocapon lucidum Booth and Tolypocladium inflatum Gams. CsA immunosuppressive properties are lymphocyte specific (cytotoxic and suppressor) and do not interfere with phagocyte functions or haemopoietic stem cells (Freitas et al., 2013). CsA treatment causes many collateral effects including cardiotoxic, nephrotoxic, hepatotoxic effects, increasing oxidative stress, hypertension vascular dysfunction, ovarian damage, testicular and spermatozoal toxicity and pulmonary disorders (Dayana et al., 2013).

L-arginine is the precursor for the synthesis of proteins and other molecules of great biological importance and it is an essential amino acid for optimal growth and development. Therefore it must be provided in the diet. For adults, Larginine is a semi-essential or conditionally essential amino acid, especially in such conditions as trauma, burn injury, small bowel resection, and renal failure. In adults, L-arginine is produced in the kidney from circulating citrulline synthesized by enterocytes in the small intestine; L-arginine administration improves cardiovascular, pulmonary, immune, digestive functions, protects against the early stages of cancerogenesis and causes protective haemodynamic alterations (Park et al., 2008).

The antioxidant properties of LArginine was due to its a- amino group and increased formation of nitric oxide (NO) as it is the immediate precursor of $\mathrm{NO}$ in the reaction mediated by the enzyme NOS (Cherian et al., 2007).

The present study aimed to to evaluate the sub-chronic toxicity ( 8 weeks) of CsA on testis, heart and lungs in adult albino rats, and to determine the potential protective effect of amino acid L-arginine.

\section{MATERIAL \& METHODS:}

\section{Material:}

\section{1-Drugs:}

Cyclosporine CsA : (Sandimmune ) oral capsules $25 \mathrm{mg}$, obtained from Novartis.

L-Arginine (powder): obtained from Sigma and dissolved in distilled water.

Olive oil: It was obtained in the form of oily solution as solvent agent for CsA.

\section{2-Animals:}




\section{Ethical consideration of the study:}

-All ethically approved conditions used for animal housing \& handling were considered. The animals were acclimatized to experimental conditions prior to the start of dosing for a period of 14 days to ascertain their physical well-being and to exclude any diseased animals. Promotion of high standard care \& animal well-being at all times. Painless procedures were performed with appropriate sedation to avoid stress \& pain (Garber et al., 2011).

A total of 48 adult male albino rats, weighing 180-200 gm, were kept on rat chow and water ad libitum at the Breeding Animal House of the Faculty of Medicine, Zagazig University. The animals were housed in filter-top plastic cages at a temperature $(23 \pm$ $\left.1^{\circ} \mathrm{C}\right)$ and artificially illuminated $(12: 12$ hours light: dark cycle) in a room free from any source of chemical contamination. All rats received human care in compliance with the guidelines of the medical research ethics committee (Semler, 1992).

\section{3- Experimental Design:}

The rats were divided into 4 groups. They were divided as follows:

Group I-control group: subdivided into 3 groups each of 8 rats:

Group Ia- Negative control group: ( 8 rats) each rat received only regular diet and water for 8 weeks to determine the basic values of performed tests.

Group Ib- Positive control group: (8 rats) each rat received olive oil $(0.5$ cc) emulsion daily by oral gavage for 8 weeks.

Group Ic- Positive control group: (8 rats) each rat received distilled water $(0.5 \mathrm{cc})$ daily by oral gavage for 8 weeks.
Group II. Cyclosporine CsA group: (8 rats) each rat received CsA $74 \mathrm{mg} / \mathrm{kg}$ (1120 of LD50) in an olive oil emulsion $(0.5 \mathrm{cc})$ daily by oral gavage for 8 weeks.

LD50 of cyclosporine is $1480 \mathrm{mg} / \mathrm{kg}$ after oral administration (Sovcikovaet al., 2002).

Group III. L-Arginine group: (8 rats) each rat received L-Arginine 300 $\mathrm{mg} / \mathrm{kg}$ daily by oral gavage for 8 weeks (Mansouret al., 2002).

Group IV. Cyclosporine CsA plus L-Arginine group: (8 rats) each rat received $300 \mathrm{mg} / \mathrm{kg} /$ day of $\mathrm{L}$ Arginine by oral gavage a week before Cyclosporine CsA treatment is initiated. The rats then received Cyclosporine CsA $(74 \mathrm{mg} / \mathrm{kg}$ in an olive oil emulsion) by oral gavage for 8 weeks (Kurus et al., 2008).

After the end of the study, rats from each group were anesthetized by ether inhalation to take blood samples from the retro-orbital plexuses of veins for performing the hormonal study (serum testosterone level). Heart, lungs and testis were removed and subjected to histopathological study.

\section{Methods:}

\section{1- Hormonal Study:}

Venous blood samples were collected from the retro-orbital plexus of veins of the animals by capillary glass tubes after under light ether anaesthesia. The collected blood was used as follows: Blood samples (about $3 \mathrm{~mL}$ ) were collected in clean test tubes without anticoagulant then the sera were separated by centrifugation of blood 3000 r.p.m for 10 minutes. The supernatant sera were pipetted off using fine tipped automatic pipettes and stored in deep freeze at $-20 \mathrm{C}$ until used for estimating serum testosterone. 
The testosterone rat/mouse

ELISA is a competitive immunoassay for the quantitative measurement of testosterone in rat serum. It is a solid phase Enzyme-Linked Immunosorbent Assay (ELISA), based on the principle of competitive binding. An unknown amount of testosterone present in the sample and a defined amount of testosterone conjugated to horseradish peroxidase compete for the binding sites of testosterone antiserum coated to the wells of a microplate. After onehour incubation on a shaker the microplate is washed four times. After addition of the substrate solution the concentration of testosterone is inversely proportional to the optical density measured (Zirkin and Chen, 2000).

\section{2- Histopathological Examination} -Hematoxylin \& Eosin stain:

After 8 weeks, rats from each group were anaesthetized with ether inhalation then sacrificed. The heart, lungs and testses were immediately dissected. Tissues from them were obtained as 5-mm thick sections, fixed with $10 \%$ neutral formalin for more than 12 hours, dehydrated, embedded in paraffin, sectioned at $5 \mu \mathrm{m}$, mounted on glass slides, and stained with hematoxylin and eosin (H\&E) stain (Bancroft and Gamble, 2002).

-Masson's Trichrome Staining

Masson's Trichrome was done to enhance the appearance of fibrosis that occurred in the myocardium due to cyclosporin exposure. Sections were deparaffinized and rehydrated through alcohol, then washed with distilled water. The sections were stained in Weigert's iron hematoxylin working solution for 10 minutes followed by rinsing in running warm tap water for 10 minutes and washed in distilled water. The stained sections were differentiated in phosphomolybdicphosphotungstic acid solution for 10-15 minutes or until collagen is not red, then transfered directly (without rinse) to aniline blue solution and stain for 510 minutes. Sections were rinsed briefly in distilled water and differentiated in $1 \%$ acetic acid solution for 2-5 minutes, then dehydrated very quickly through alcohol and cleared in xylene (Carson, 2009).

\section{3- Statistical Analysis:}

For statistical analysis, SPSS 16.0.1 for windows programme was used. Data was represented as means \pm $\mathrm{SD}$. The differences were compared for statistical significance by ANOVA test. Statistical difference between groups was calculated by LSD. Difference was considered significant at $\mathrm{p}<0.05$.

\section{RESULTS}

Biochemical Results: Testosterone Level;

Biochemical findings of serum testosterone $(\mathrm{ng} / \mathrm{ml})$ of the control groups negative $\&$ positive (I.a, I.b \& I.c) and group III were within normal values and there were no statistically significant differences $(p>0.05)$ between them (Table -1). So the results of the positive control group (I.b) were used for comparison with those of both treated groups.

Processing the mean values of serum testosterone $(\mathrm{ng} / \mathrm{ml})$ of the adult male albino rats of group II \& IV revealed that there were significant differences between them (Table-2).

Analysis of variance (ANOVA or $f$ test) of the mean values of serum testosterone among positive control group (I.b), group II and group IV revealed that there were highly statistically significant differences in 
the mean values of serum testosterone (ng/ml) by the end of $8^{\text {th }}$ week (Table3).

\section{B- Histopathological Results:}

\section{a- The testes}

Examination was done for sections from the testes tissue of control groups (Group I.a, I.b and I.c) and Group III. L-Arginine treated group showed normal testicular structure with seminiferous tubules and spermatocytes (Figure 1). While the testicular sections of cyclosporine treated group (group II) revealed marked pathological changes in the form of extensive degeneration of seminiferous tubules, necrosis and interstitial edema (Figure 2). While group IV (Cyclosporine CsA plus LArginine treated group) most of Seminiferous tubules retain its normal structure, few show degeneration and necrosis (Figure 3).

\section{b- The heart}

Examination was done for sections from the heart tissue of control groups (Group I.a, I.b and I.c) and Group III. L-Arginine treated group showed normal cardiac tissue. There were branching and anastomosing cardiac muscle fibers in different directions contained oval central nuclei. Connective tissue cells and fibers were found between the cardiac muscle fibers (Figure 4). While the heart sections of cyclosporine treated group (group II) revealed marked pathological changes in the form of extensive connective tissue formation among myocardial fibers with disorganization of myocardial fibers (Figures-5\&6), while group IV (Cyclosporine CsA plus
L-Arginine treated group) showed mild connective tissue formation (Figure 7).

Also, Masson's Trichrome Stained sections from the heart tissue of control groups (Group I.a, I.b and I.c) and Group III. L-Arginine treated group showed normal morphology, composed of striated muscle fibers and sparse connective tissue (Figure 8). While the heart sections of CsA treated group (group II) revealed increased connective tissue among myocardial fibers with extensive fibrosis (the blue colour indicates connective tissue) (Figure 9), while group IV (Cyclosporine CsA plus L-Arginine treated group) mild myocardial disorganization and sparse connective tissue among myocardial fibers were seen (Figure 10).

\section{c- The lungs}

Lungs tissue of control groups (Group I.a, I.b and I.c) and Group III LArginine treated group showed normal spongy histological structure and architecture of the lung with alveoli, alveolar sacs, thin and thick portions of interalveolar septa. The alveoli appeared patent with thin interalveolar septa (Figure 11). While the lungs sections of cyclosporine treated group (group II) revealed marked pathological changes in the form of large area of acute bronchopneumonia, many alveolar walls are covered by fibrin exudates and inflammatory cellular infiltrate (Figure 12). While group IV (Cyclosporine CsA plus L-Arginine treated group) showed edematous thickening of the alveolar walls and sparse inflammatory cellular infiltrate (Figure 13). 
Table (1): Statistical comparison between the mean values of serum testosterone $(\mathrm{ng} / \mathrm{ml})$ levels of adult male albino rats of the positive, negative control group and L-Arginine group by f-test:

\begin{tabular}{|c|c|c|c|c|c|c|}
\hline Parameters/period & $\begin{array}{l}\text { +ve } \\
\text { control } \\
\text { group } \\
\text { (I.b) }\end{array}$ & $\begin{array}{l}\text { +ve } \\
\text { control } \\
\text { group } \\
\text { (I.c) }\end{array}$ & $\begin{array}{l}\text {-ve } \\
\text { control } \\
\text { group } \\
\text { (I.a) }\end{array}$ & $\begin{array}{l}\text { L- } \\
\text { Arginine } \\
\text { group } \\
\text { (III) }\end{array}$ & f-test & $\begin{array}{c}\text { P- } \\
\text { value }\end{array}$ \\
\hline $\begin{array}{l}\text { Testosterone by the } \\
\text { end of } 8^{\text {th }} \text { week } \\
\left(X^{-} \pm \text {SD) }\right.\end{array}$ & $6.3 \pm 0.60$ & $6.25 \pm 0.8$ & $6.1 \pm 1.2$ & $5.9 \pm 0.9$ & 0.368 & 0.697 \\
\hline
\end{tabular}

Number of rats $=8$ rats for each group $\quad(P>0.05)$ : non significant

SD: standard deviation

Table (2): Statistical comparison between the mean values of serum testosterone (ng/ml) levels of adult male albino rats between groups (II) \& (IV):

\begin{tabular}{|l|c|c|c|c|}
\hline Parameters/period & $\begin{array}{c}\text { CsA treated } \\
\text { group (II) }\end{array}$ & $\begin{array}{c}\text { CsA +L- } \\
\text { Arginine group } \\
\text { (IV) }\end{array}$ & t-test & P-value \\
\hline $\begin{array}{l}\text { Testosterone by the end of } \\
\mathbf{8}^{\text {th }} \text { week }\left(\mathbf{X}^{-} \pm \text {SD) }\right.\end{array}$ & $2.0 \pm 0.3$ & $3.6 \pm 0.1$ & 14.311 & $0.0001^{*}$ \\
\hline
\end{tabular}

Number of sacrificed rats for each group was 8 rats. * highly significant

Table (3): Statistical comparison between the mean values of serum testosterone (ng/ml) levels of adult albino rats among group II, IV and the positive control group I.b by the end of $8^{\text {th }}$ week by ANOVA test:

\begin{tabular}{|l|c|c|c|c|c|}
\hline Parameters/period & $\begin{array}{c}\text { CsA } \\
\text { treated } \\
\text { group (II) }\end{array}$ & $\begin{array}{c}\text { CsA+L- } \\
\text { Arginine } \\
\text { group(IV) }\end{array}$ & $\begin{array}{c}\text { +ve } \\
\text { control } \\
\text { group } \\
\text { (Ib) }\end{array}$ & f-test & $\begin{array}{c}\text { P- } \\
\text { value }\end{array}$ \\
\hline $\begin{array}{l}\text { Testosterone by the } \\
\text { end of } \mathbf{8}^{\text {th }} \text { week } \\
\left(\mathbf{X}^{-} \pm \text {SD) }\right.\end{array}$ & $2.0 \pm 0.3$ & $3.6 \pm 0.1$ & $6.3 \pm 0.60$ & 246.435 & $0.000^{*}$ \\
\hline
\end{tabular}

Number of sacrificed rats for each group was 8 rats. * highly significant 


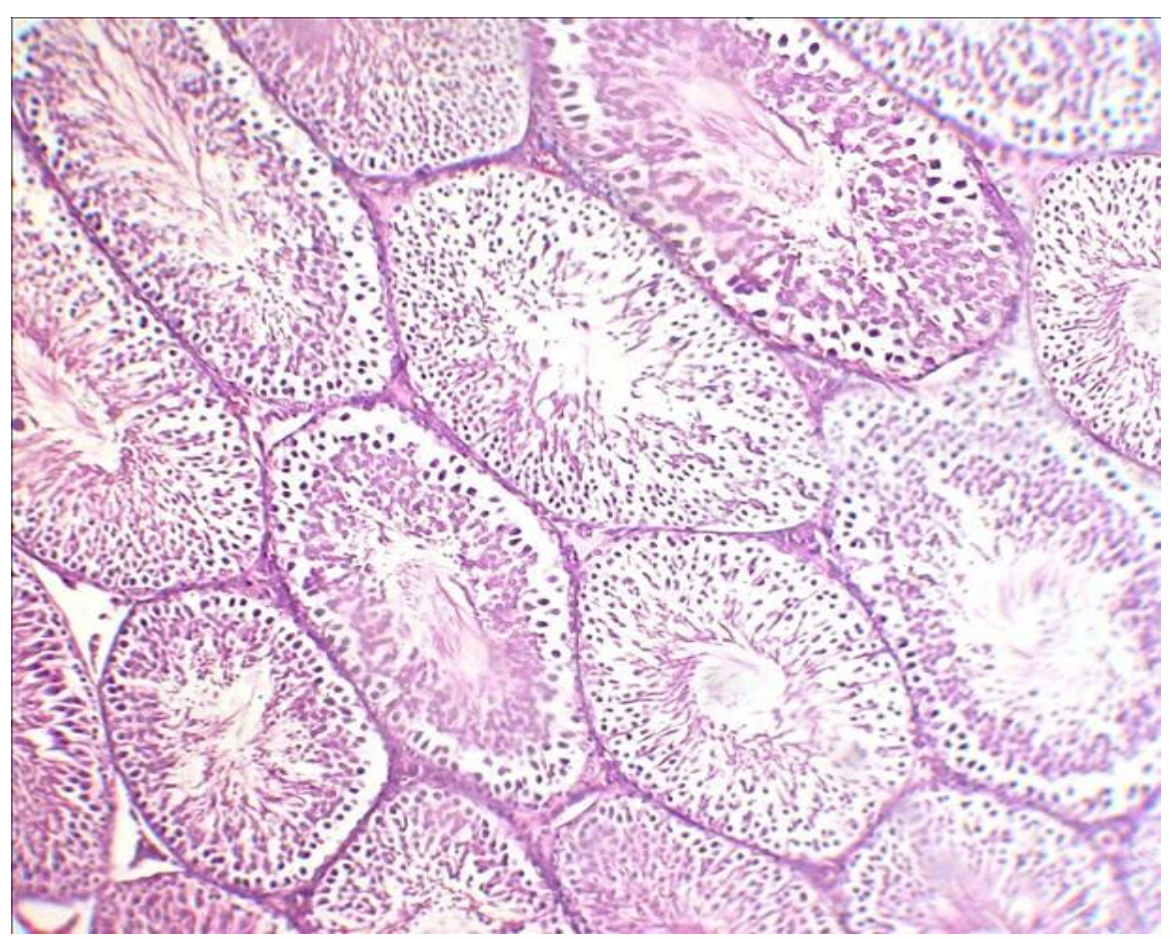

Figure (1): A photomicrograph of a section in the testis of adult albino rat from the control groups and L-Arginine treated group showing normal testis structure composed of seminefrous tubules their lumen show aggregation of sperms and normal thickness of the basement membrane (H\&Ex200).

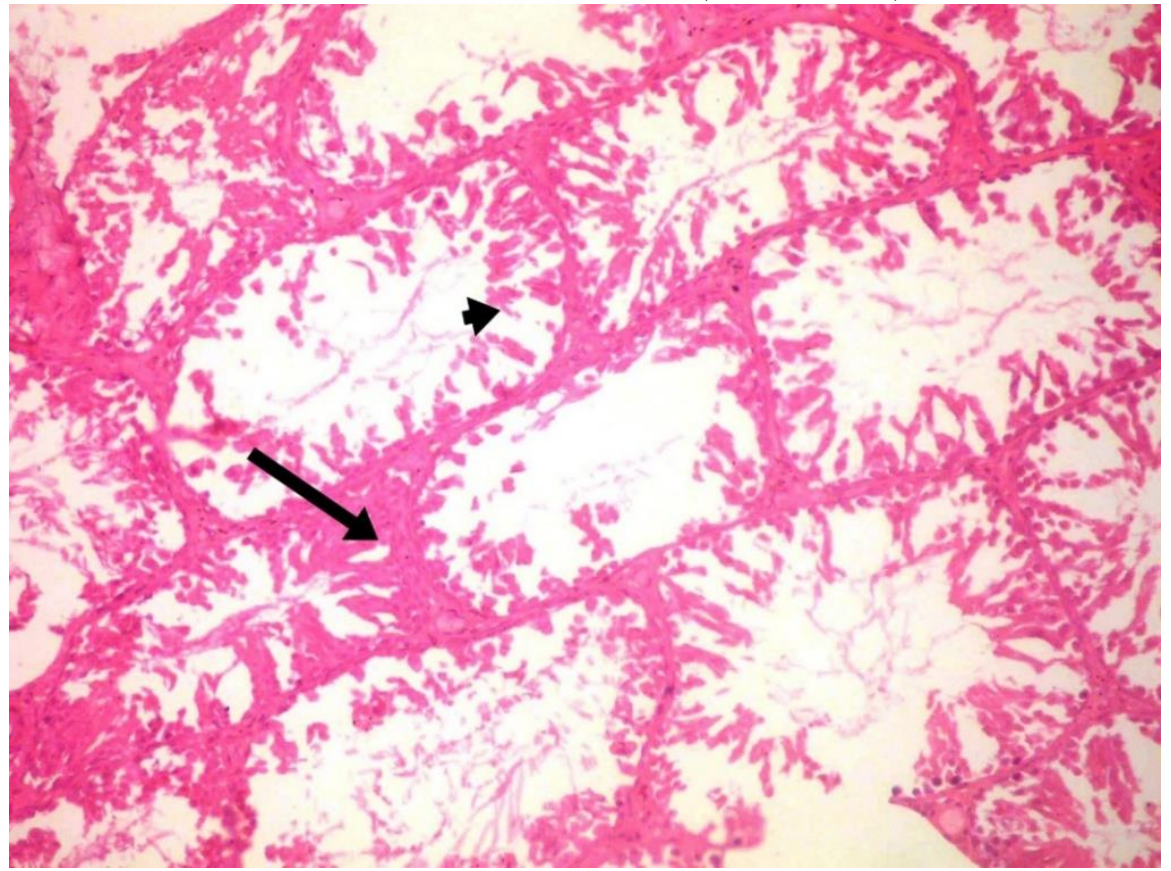

Figure (2): A Photomicrographs of testicular tissue and seminiferous tubules from an adult male albino rat of Cyclosporine treated group showed extensive degeneration, necrosis (arrow head) and interstitial edema (arrow) (H\&Ex200). 


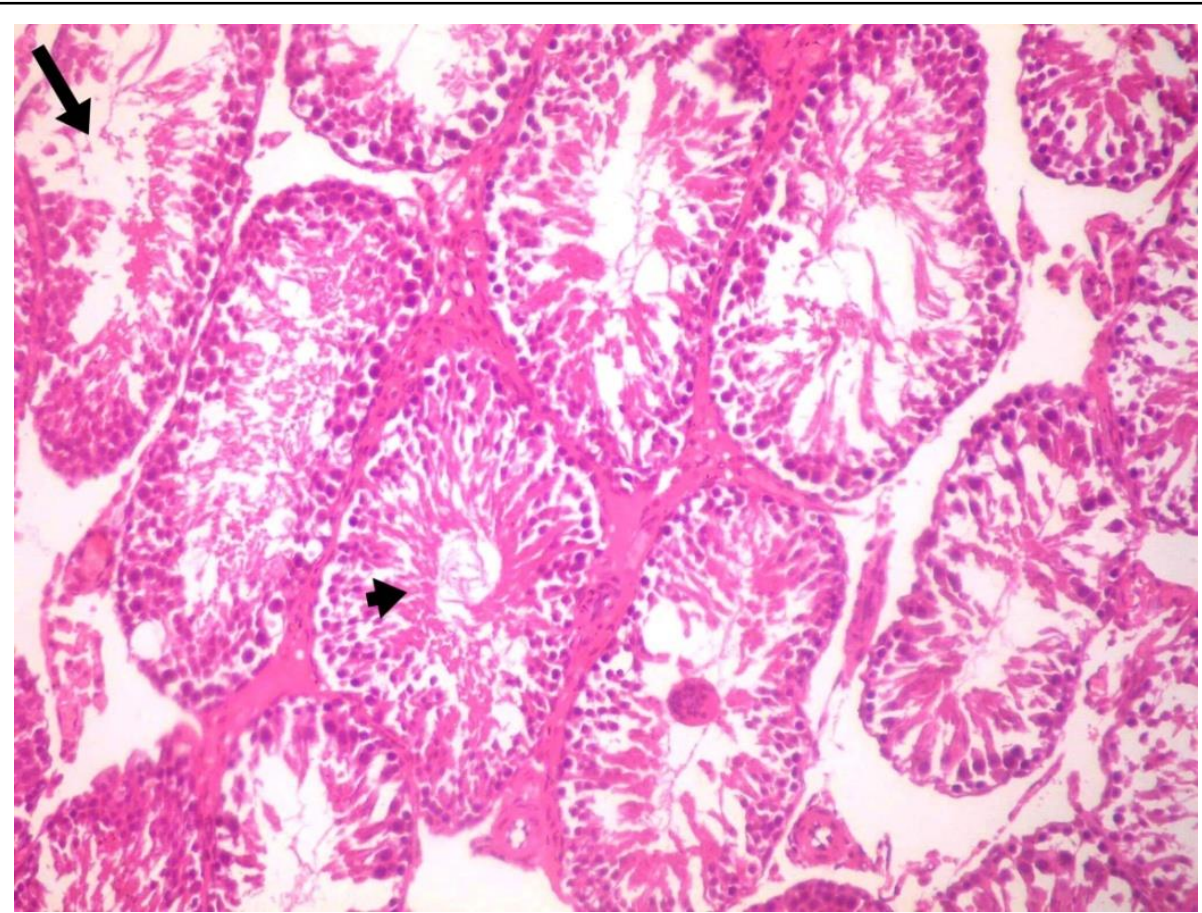

Figure (3): A Photomicrographs of testicular tissue and seminiferous tubules from an adult male albino rat of of Cyclosporine plus L-Arginine treated group. Most of Seminiferous tubules retain its normal structure (arrow head), others show degeneration and necrosis (arrow) (H\&Ex200).

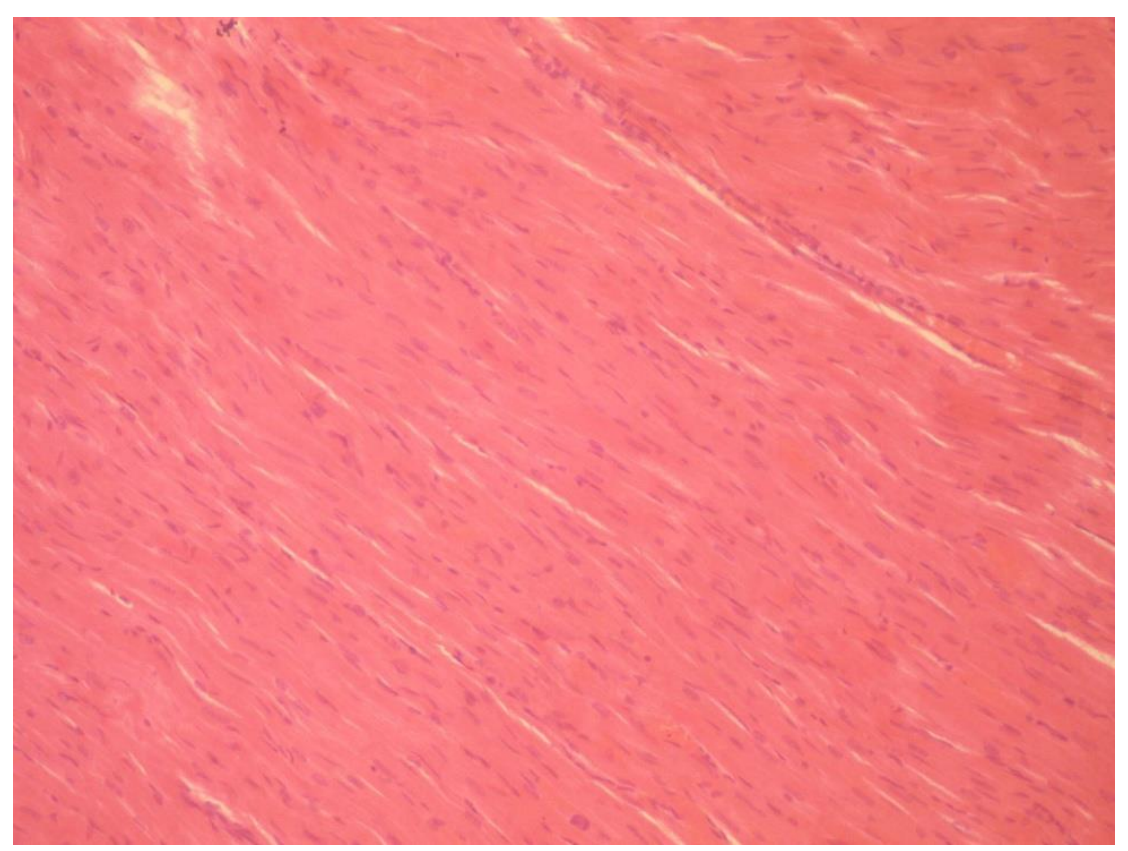

Figure (4): A photomicrograph of myocardium from an adult male albino rat of the control groups and L-Arginine treated group rats showed almost normal cardiac tissue. There were branching and anastomosing cardiac muscle fibers in different directions contained oval central nuclei. Connective tissue cells and fibers were found between the cardiac muscle fibers (H\&E x200). 


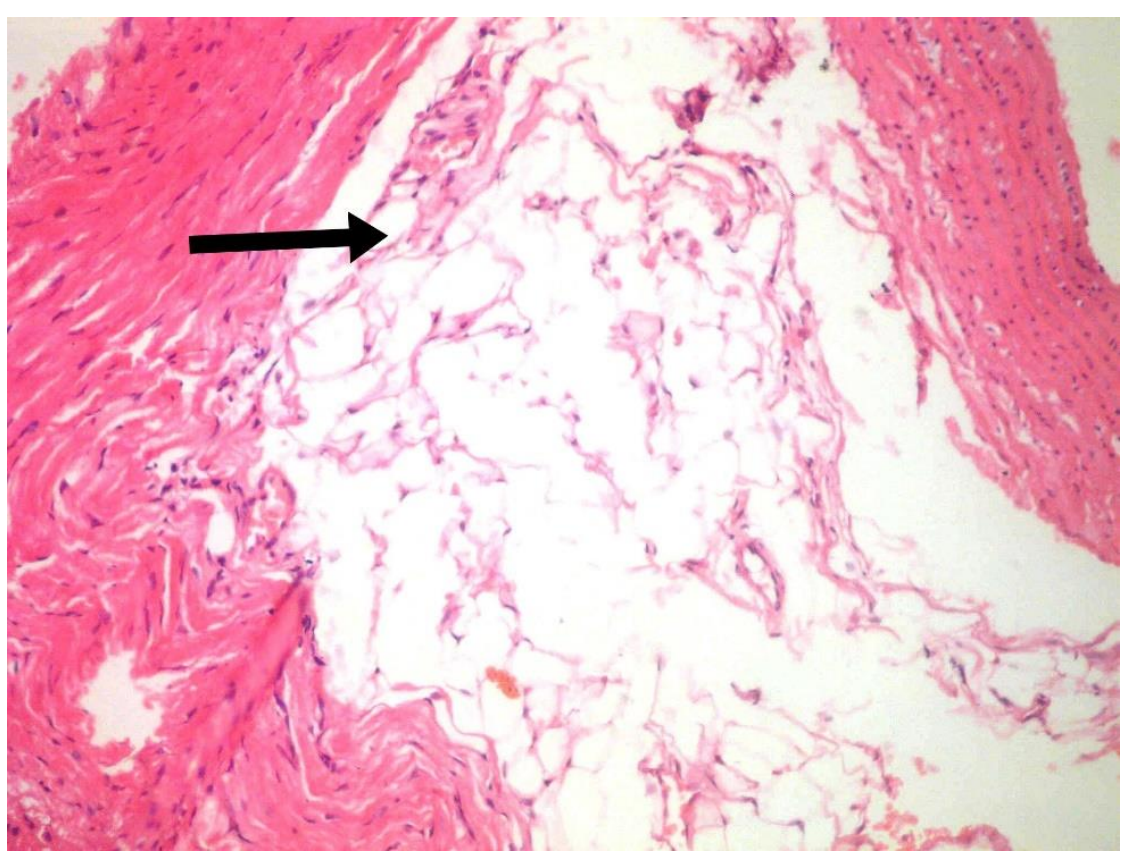

Figure (5): A Photomicrographs of myocardium from an adult male albino rat of the cyclosporine treated group showed extensive connective tissue formation among myocardial fibers with disorganization of myocardial fibers. ( $H \& E \times 200$ ).

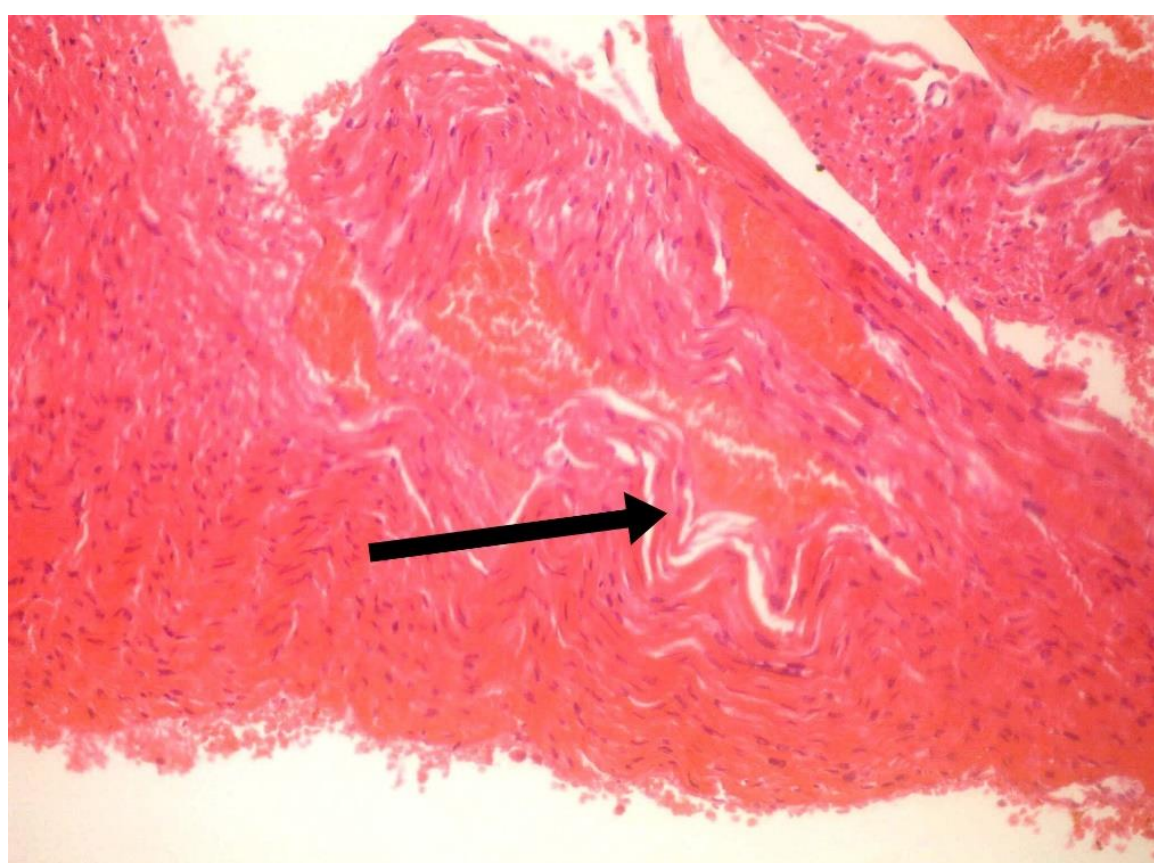

Figure (6): A Photomicrographs of myocardium from an adult male albino rat of the cyclosporine treated group showed myocardial fibers disorganization ( $\mathrm{H} \& \mathrm{E}$ $\mathrm{x} 200)$. 


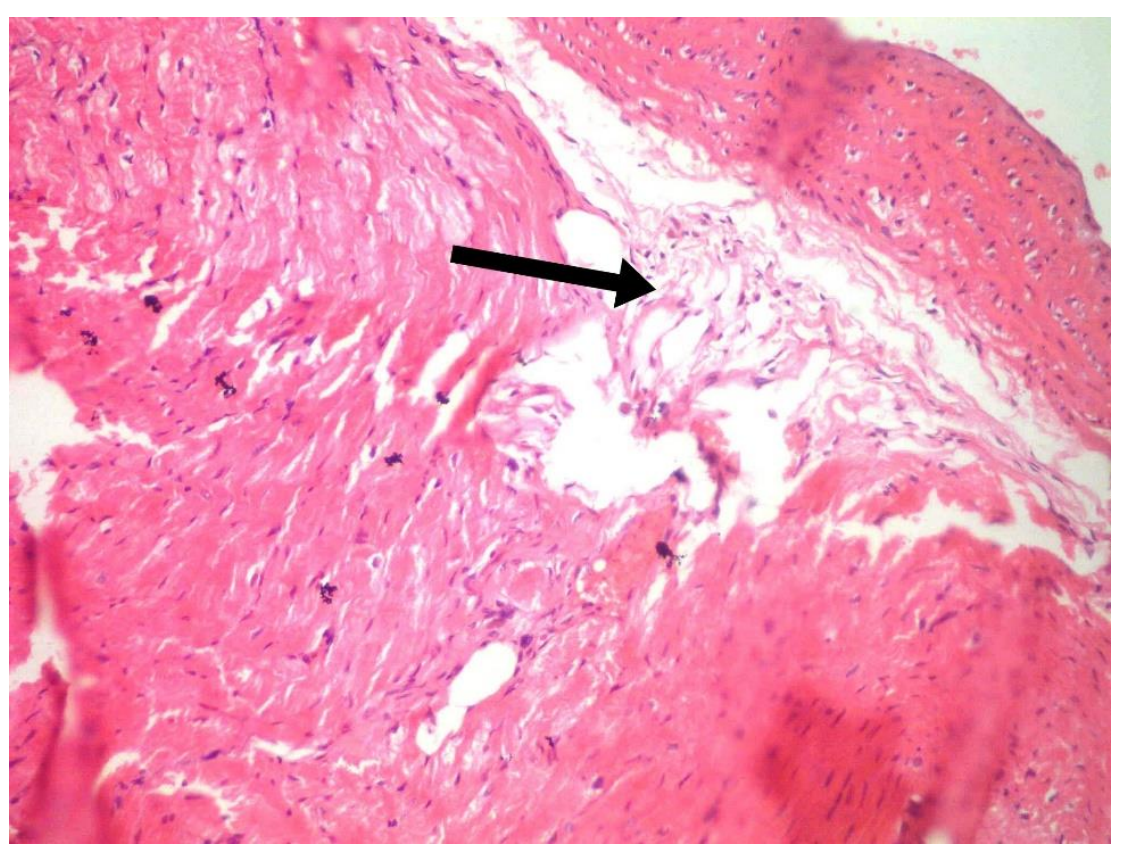

Figure (7): A Photomicrographs of myocardium from an adult male albino rat of the Cyclosporine plus L-Arginine treated group showed mild connective tissue formation in $(\mathrm{H} \& \mathrm{E} \times 200)$.

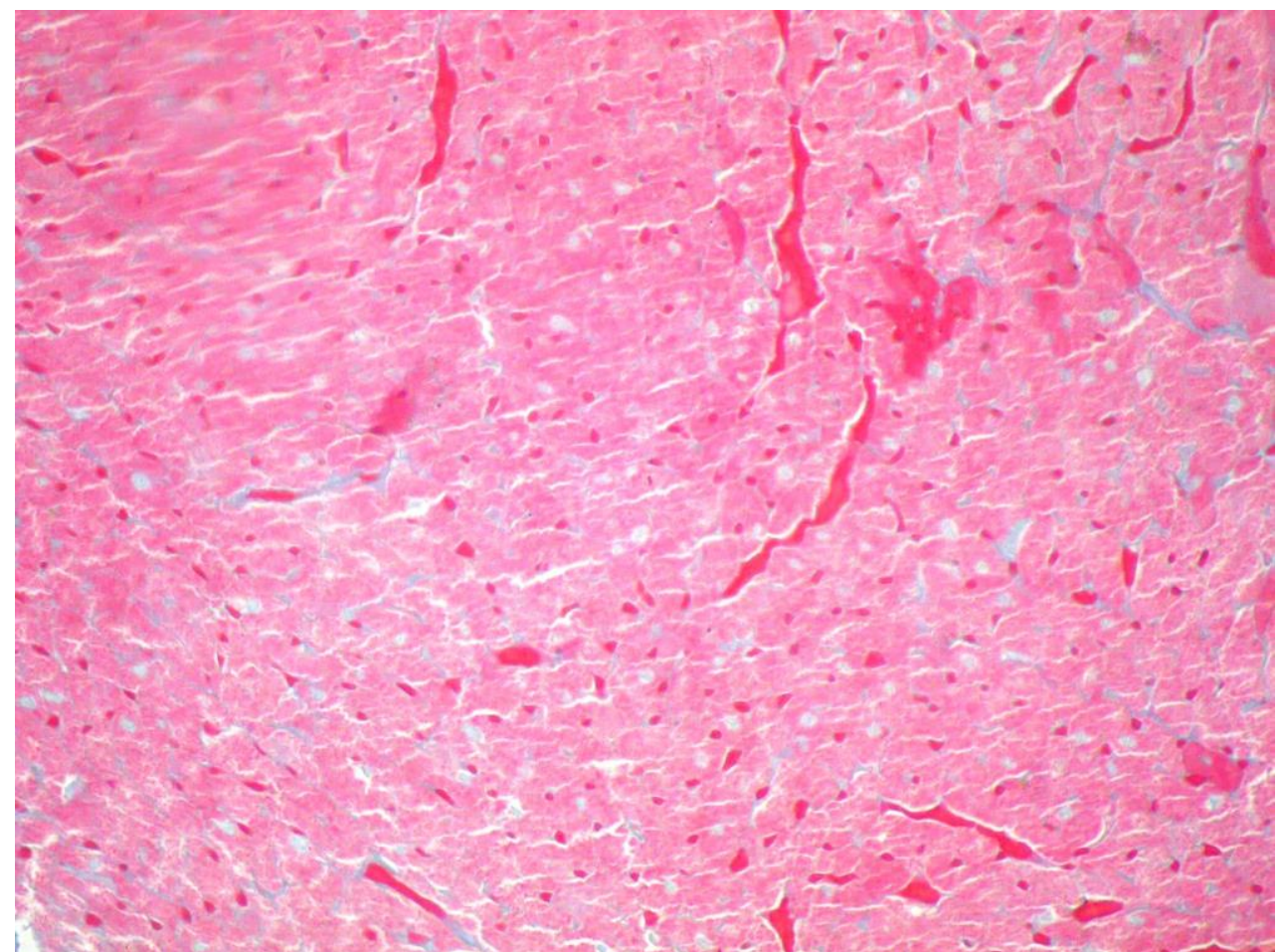

Figure (8): A Photomicrographs of myocardium from an adult male albino rat of the control groups and L-Arginine treated group show normal morphology, composed of striated muscle fibers and sparse connective tissue. (Trichrome stain $\mathrm{x} 400$ ). 


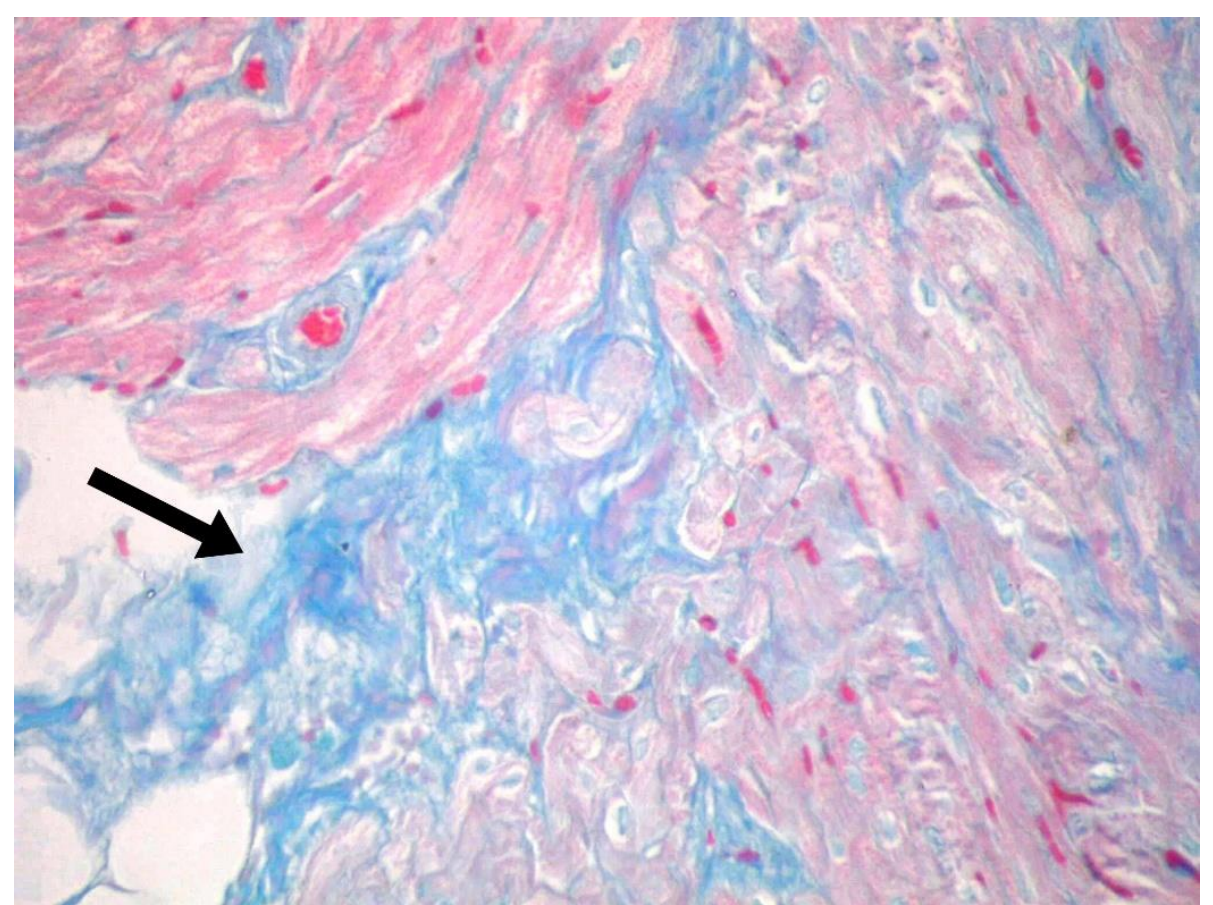

Figure (9): A Photomicrographs of myocardium from an adult male albino rat of cyclosporine treated group showed increased connective tissue among myocardial fibers with extensive fibrosis. (The blue colour indicates connective tissue).(Trichrome stain $\mathrm{x} 400$ ).

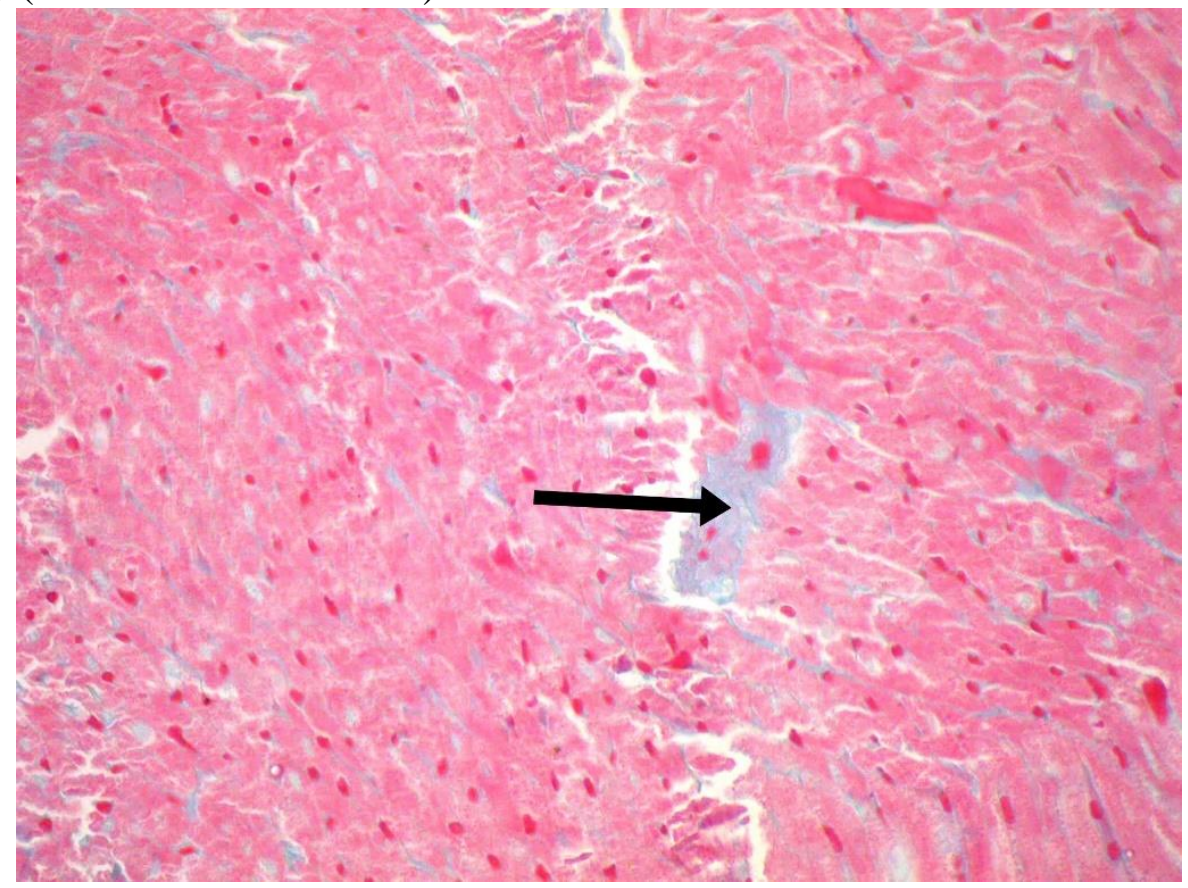

Figure (10): A Photomicrographs of myocardium from an adult male albino rat of the Cyclosporine CsA plus L-Arginine treated group. Mild myocardial disorganization (arrow) and sparse connective tissue among myocardial fibers are seen. (Trichrome stain $\times 400$ ). 


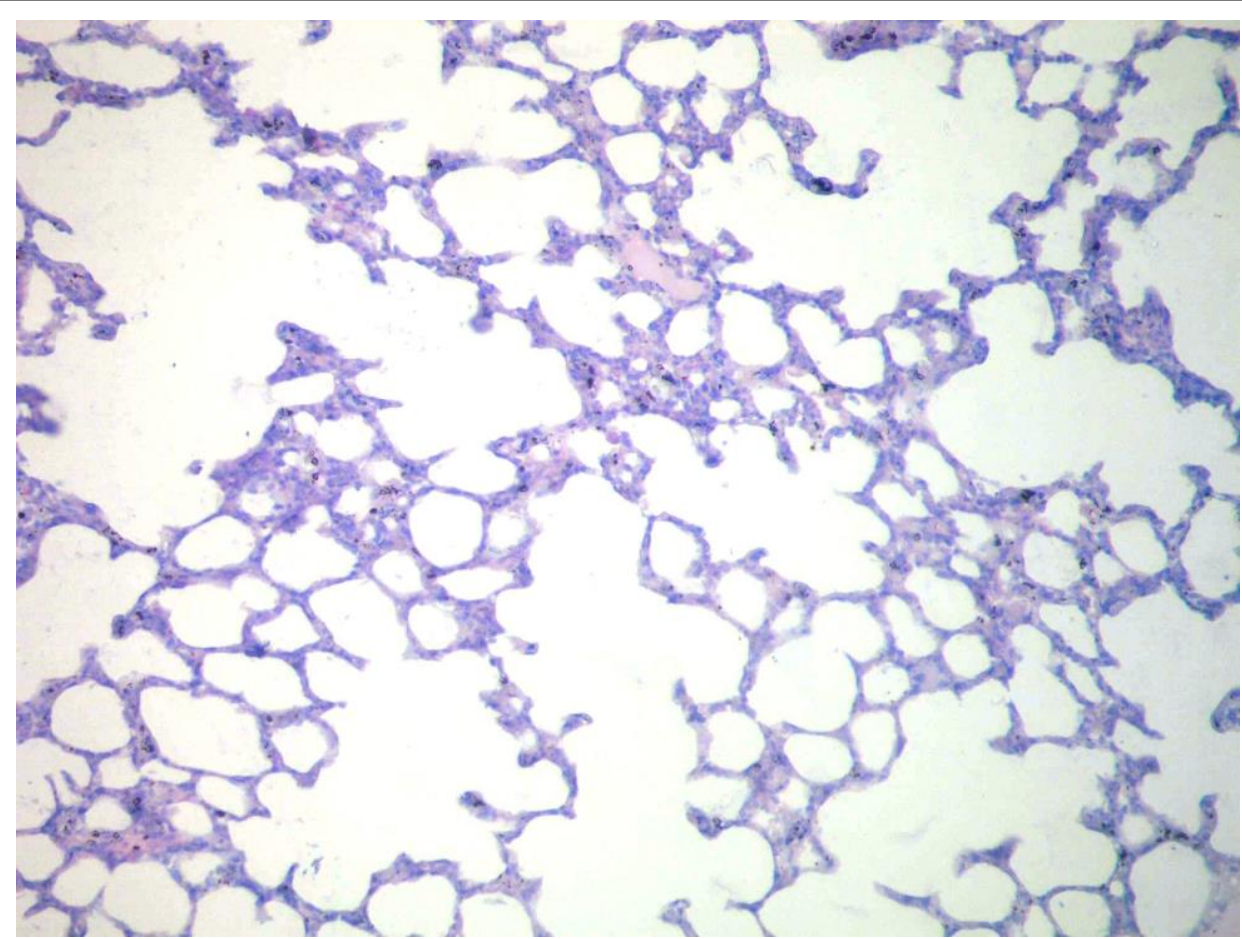

Figure (11): A Photomicrographs of lung from an adult male albino rat of control groups and L-Arginine treated group showed normal architecture of the lung with alveoli, alveolar sacs, thin and thick portions of interalveolar septa. The alveoli appeared patent with thin interalveolar septa (H\&E x 200).

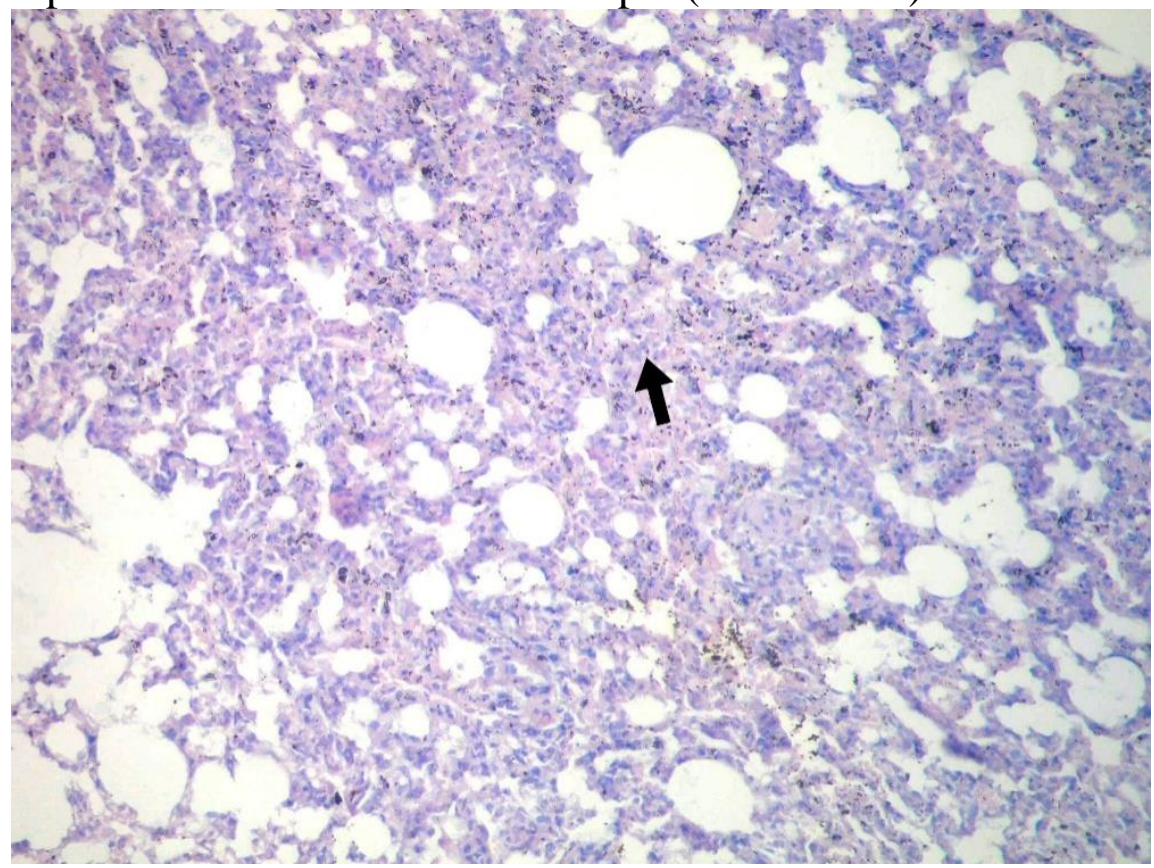

Figure (12): A Photomicrographs of lung from an adult male albino rat of cyclosporine treated group showed large area of acute bronchopneumonia. Many alveolar walls are covered by fibrin exudates and inflammatory cellular infiltrate ( H\&Ex200). 


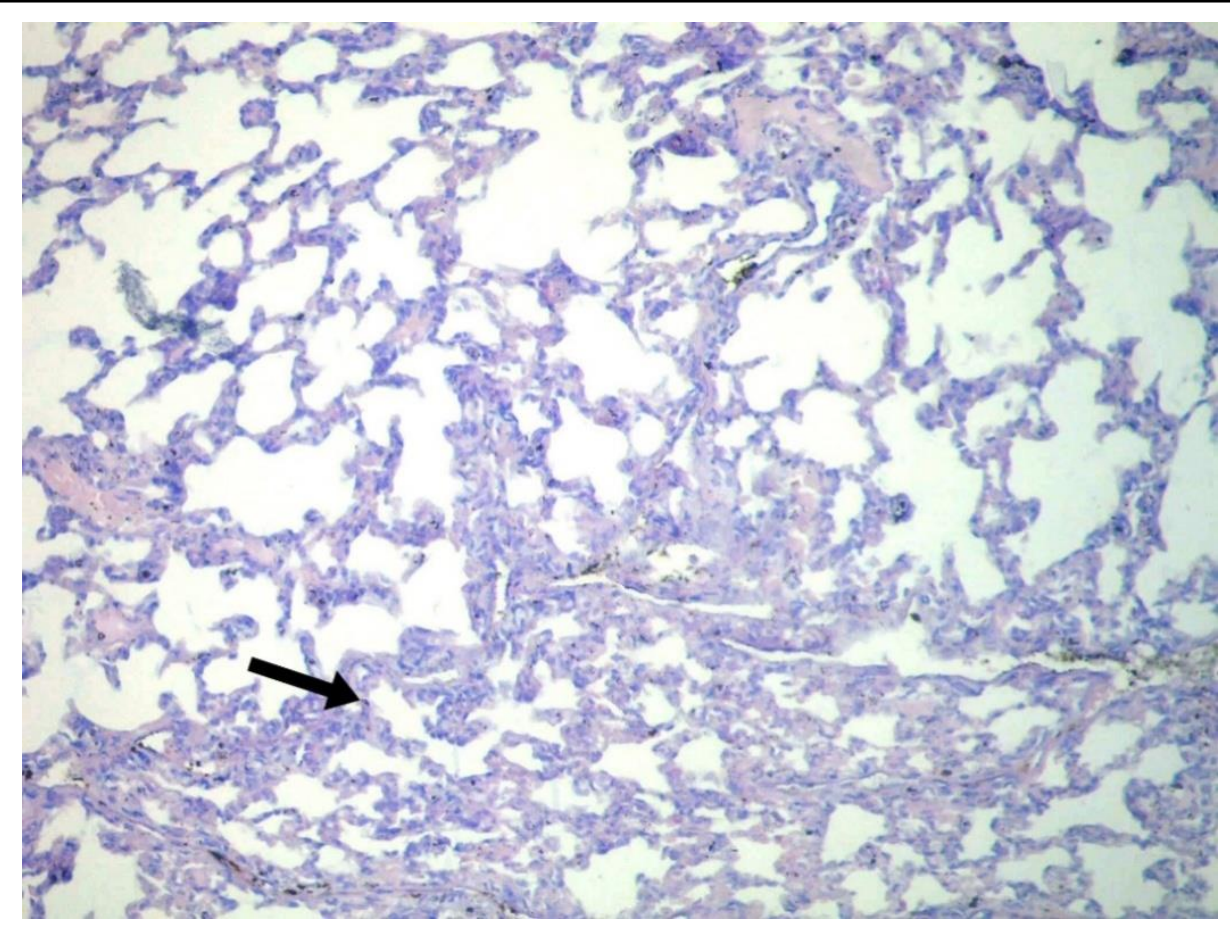

Figure (13): A Photomicrographs of lung from an adult male albino rat of Cyclosporine CsA plus L-Arginine treated group showed edematous thickening of the alveolar walls and inflammatory cellular infiltrate (H\&Ex200).

\section{DISCUSSION}

Cyclosporine is one of the most important component commonly used in immunosuppressive regimens, which have resulted in a dramatic improvement in the outcomes observed in renal transplant recipients over the past 30 years (Chen et al., 2013). So, the use of CsA has improved quality of life and survival of transplant patients by largely contributing to the decrease in morbidity, rejection reactions and hospitalization days. However, clinical use of CsA is limited due to its unwanted side-effects in different organs such as kidney, heart, liver in transplanted patients (Türk et al., 2010).

\section{Biochemical Results:}

As regard biochemical results, in the present study the Cyclosporine treated group II: CsA orally gavaged for 8 weeks resulted in significant decrease in the serum testosterone $(\mathrm{ng} / \mathrm{ml})$ levels in adult male albino rats as compared with the control groups.

The results are in agreement with He et al. (2013) who observed that testosterone was significantly lower in CsA treated groups after 8 weeks as compared to control group

Also, these results are in accordance with Chen et al. (2013) who noticed a decrease in serum testosterone level along with elevated levels of gonadotropins, significant impairment of spermatogenesis, and evidence of severe testicular injury in both light and electron microscopic examination in rats that received cyclosporine for 8 weeks.

These results can be explained by Park et al. (2010) who reported that oral administration of CsA impaired testosterone synthesis mainly by inhibiting the hypothalamopituitary axis function. A decline in testosterone biosynthesis in a dose- 
dependent manner is attributable to blocking the signal transduction pathway.

\section{Histopatholoical Results:}

The testes:

These biochemical results further confirmed by histopatholgical damage of testis which appeared in the form of marked pathological changes such as extensive degeneration of seminiferous tubules, necrosis and interstitial edema.

These results are in agreement with Türk et al. (2007) who observed degeneration, necrosis and interstitial edema in testis of CsA-treated group when compared to the control group. The author explained the damage due to the direct effect of CsA inducing impaired maturation or release of spermatozoa or by indirect effect in which CsA induces lipid peroxidation that is a chemical mechanism capable of disrupting the structure and function of testis.

Also, the study results are near to Türk et al. (2010) who observed atrophy in seminiferous tubules, necrosis in germinal cells, degeneration, interstitial edema, capillary congestion and spermatogenic arrest were marked damages in testicular tissue in cyclosporine group.

The possible mechanisms indicated that administration of CsA results in a dose-dependent decline in body and reproductive organ weights, degenerative changes of seminiferous tubules, and impaired spermatogenesis in rats, which is not likely secondary to the potential hepatic or nephrotoxic effects of the drug. Direct alteration in the hypothalamic-pituitary-gonadal axis, reduction in Sertoli cell phagocytic function, and oxidative stress in testicular tissues have primarily contributed to the pathogenesis of the observed testicular and spermatozoal toxicities induced by cyclosporine Caneguim et al. (2009)

The heart:

Administration of CsA for 8 weeks resulted in remarkable histopathological changes in the form of extensive connective tissue formation among myocardial fibers with disorganization of myocardial fibers. Moreover, Masson's Trichrome Stained sections of CsA treated group (group II) revealed extensive fibrosis.

The obtained results are near to Ebru et al. (2008) who reported pathological changes after CsA administration at a dose of ( $25 \mathrm{mg} / \mathrm{kg}$, orally for 21 days). These changes were in the form of inflammatory cell infiltration, disorganization of myocardial muscle fibres and interstitial fibrosis. Infiltrated cells were mostly composed of mature lymphocytes. Connective tissue was clearly increased and fibrosis was evident around myocardial fibres.

It seems that CsA can cause excess of free radical production during its metabolism, and/or impair antioxidant system. Cyclosporine A treatment of rat cardiomyocytes induces a characteristic alteration of intracellular calcium and oxidative stress that could explain the toxicity in the treated rat heart (Rezzani et al., 2005).

Although the mechanisms by which cyclosporine A induced cardiotoxicity are still not clear and is a matter of debate, recent studies have reported that oxidative stress might be a possible factor underlying in the pathogenesis. Oxidative stress, characterized by an imbalance between increased exposure to free radicals and antioxidant defences, is a prominent feature of many acute and chronic 
diseases. Under oxidative stress conditions, the endogenous antioxidants, such as catalase (CAT), superoxide dismutase (SOD) and glutathione, may be unable to counter reactive oxygen species. Hence, their presence may cause cellular damage by peroxidation of membrane lipids, sulfhydryl enzyme inactivation, protein cross-linking and DNA breakdown (Rezzani et al., 2009). Another mechanism might be vascular endothelial dysfunction. Vasodilators, such as prostacyclin and nitric oxide, were suppressed, while vasoconstrictors, including endothelin, were increased (Ilhan et al., 2004).

The lungs:

In the present study, remarkable histological changes in the form of marked pathological changes were detected as large area of acute bronchopneumonia, many alveolar walls are covered by fibrin exudates and inflammatory cellular infiltrate after 8 weeks of CsA administration at a dose of $74 \mathrm{mg} \backslash \mathrm{kg} \backslash$ day.

These results are in accordance with Elshama et al. (2016) who revealed that CsA at a dose of $40 \mathrm{mg} / \mathrm{kg} /$ day induced marked pulmonary histopathological abnormalities such as a pyknotic nucleus of pneumocyte type II, degeneration of alveoli with its microvilli, emphysema with inflammatory cellular infiltration and pulmonary vessels congestion.

The possible mechanism of toxicity is generation of free radicals inducing oxidative stress leads to molecular and cellular damage which are considered the cause of cyclosporine toxic effects on the different body organs. The effects of released reactive oxygen species (ROS) by normal respiratory system are counteracted by glutathione and antioxidants enzymes such as catalase and peroxidase; therefore more generation of ROS via cyclosporine leads to the balance disturbance with antioxidants defense mechanism inducing toxic cellular substances which lead to histopathological changes (Lee, 2010). Cyclosporine affects the cell of lung tissues as a result of multiple effects such as carbohydrates depletion in the cytoplasm of lung cell that leads to the lung structure disturbance (Yousef and ALRajhi, 2013)

Another explanation had been proposed by Van Thiel (1989) that, a few case reports dealing with severe and sometimes fatal opportunistic pulmonary infections have been reported. Importantly, these infections occurred during high-dose cyclosporine treatment in combination with corticosteroids.

Group IV Cyclosporine CsA plus L-Arginine group

In the present study, oral gavage with L-Arginine caused partial improvement in the histopathological changes. Testis showed that most of seminiferous tubules retain its normal structure, few show degeneration and necrosis. The heart, showed mild myocardial disorganization and sparse connective tissue among myocardial fibers and the lung showed edematous thickening of the alveolar walls and sparse inflammatory cellular infiltrate.

Cyclosporine accused of inducing oxidative stress damage in testicular tissues that have primarily contributed to the pathogenesis of the observed testicular and spermatozoal toxicities induced by CsA (Chen et al., 2013). Reactive oxygen species (ROS) are normally synthesized in several essential metabolic processes for living 
cells including the spermatozoa. ROS are highly reactive and can react with many intracellular molecules, mainly unsaturated fatty acids according to Cid et al. (2003) that cause many disorders like decrease level of testosterone. Morover, ROS can attack and damage all types of macromolecules and they have been attributed, at least partly, to CsA toxicity. Recent studies show evidence that many antioxidant substances can alleviate the CsA toxicity (Lee, 2010).

The protective effects of L-arginine administration are suggested due to its ability to serve as a substrate for the NO-synthase needed for the formation of NO. Also, it is able to delay the cellmediated breakdown of NO. NO is a potent antioxidant that can elicit antiinflammatory effects by scavenging certain reactive oxygen species and it can prevent the oxidation of lipoprotein. Moreover, NO deficiency is generally associated with upregulation of oxidation-sensitive genes, whereas increased NO production leads to decreased expression of oxidationsensitive genes. NO is synthesized by NOS, which utilizes L-arginine as substrate and produces L-citrulline as the second reaction product. L-arginine can be synthesized from L-citrulline in endothelial and other cell types, thereby providing a recycling pathway for the conversion of L-citrulline to NO via Larginine (Hayashi et al., 2005) and this can explain the partial improvement by administration of L-Arginine as proved in the present study.

Antioxidant effect using is known to protect tissues from damage caused by oxidative stress has been recently reported (Rezzani et al., 2009) CsA induced organ toxicity that accompanies lipid peroxidation and the expression of the isoform of inducible nitric oxide and apoptosis can be reduced by antioxidant and this can explain the improvement occurred with L-Arginine administration.

\section{CONCLUSION}

From the previous results, it can be concluded that CsA induced toxic effects in the testis as evidenced by biochemical and histopathological changes. Also, heart and lungs showed histopathological damage. Pretreatment with L-Arginine group (IV) can reduce the subsequent CsA injury in testis, heart and lungs. Further studies are highly recommended to elucidate the exact mechanism(s) of protection.

\section{REFERENCES}

Bancroft, J.D. and Gamble, M. (2002): Theory and practice of histological techniques.5th ed. (Eds).New York, London, Pheladelphia: Churchill Livingstone.

Caneguim, B.H.: Cerri, P.S.; Spolidório, L.C.; Miraglia, S.M. and Sasso-Cerri, E. (2009): Structural alterations in the seminiferous tubules of rats treated with immunosuppressor tacrolimus. Reprod Biol Endocrinol; 7(1): 19.

Carson, F. (2009): This REF for Trichrome. In: Histotechnology A Self-Instructional Text. $1^{\text {st }}$ ed. (Eds). ASCP. pp 142-143.

Chen, Y.; Zhang, Z.; Lin, Y.; Lin, H.; Li, M.; Nie, $P$ and $X u, B$. (2013): Long-term impact of immunosuppressants at therapeutic doses on male reproductive system in unilateral nephrectomized rats: a comparative study. BioMed 
research international. http://dx.doi.org/10.1155/2013/690 382

Cherian, L.; Chacko, G.; Goodman, C. and Robertson, C.S. (2003): Neuroprotective Effects of LArginine Administration after Cortical Impact Injury in Rats: Dose Response and Time Window. Journal of Pharmacology and Experimental Therapeutics; 304(2):617-623

Cid, T. P.; Garcí, J. C.; Alvarez, F. C. and De Arriba, G. (2003): Antioxidant nutrients protect against cyclosporine A nephrotoxicity. Toxicology; 189(1): 99-111..

Dayana, J. and Parameswari, C. S. (2013): Review paper. Emerging Novel Phytochemicals as Immunosuppressants- Review. Journal of Advanced Pharmaceutical Research; 4(1): 3345.

Ebru, U.; Burak, U.; Yusuf, S.; Reyhan, B.; Arif, K.; Faruk, T. H. and Kemal, E. (2008). Cardioprotective effects of Nigella sativa oil on cyclosporine A-induced cardiotoxicity in rats. Basic \& clinical pharmacology \& toxicology; 103(6): 574-580.

Elshama, S.; El-Kenawy, A.E.M. and Osman, H.E.H.( 2016) Histopathological study of cyclosporine pulmonary toxicity in the rats. Journal of Toxicology http://dx.doi.org/10.1155/2016/297 $\underline{3274}$

Freitas, K. M.; Monteiro, J. C.; Gomes, M. L.; Taboga, S. R. and Dolder, H. (2013): Heteropterys tomentosa (A. Juss.) infusion counteracts Cyclosporin a side effects on the ventral prostate. BMC complementary and alternative medicine; 13(1): 1 .

Garber, J. C.; Barbee, R. W.; Bielitzki, J. T.; Clayton, L. A.; Donovan, J. C.; Hendriksen, C. F. M. and Quimby, F. W. (2011): Guide for the care and use of laboratory animals. Washington DC : The National Academic Press, PP 220.

Hayashi, T.; Juliet, P.A.; MatsuiHirai, H.; Miyazaki, A.; Fukatsu, A.; Funami, J.; Iguchi, A. and Ignarro, L.J. (2005): L-Citrulline and L-arginine supplementation retards the progression of highcholesterol-diet-induced

atherosclerosis in rabbits. Proceedings of the National Academy of Sciences of the United States of America; 102(38):1368113686.

He, Z.; Qiu, J.; Li, J. ; Chen, G., and Chen, L. (2013): Long-term effects of conversion from cyclosporine to rapamycin on testicular function and morphology in a rat transplantation model. In Transplantation proceedings; 45(2) : 763-769.

Heo, S. B.; Lim, S. W.; Jhun, J. Y.; La Cho, M.; Chung, B. H. and Yang, C. W. (2016): Immunological benefits by ginseng through reciprocal regulation of Th17 and Treg cells during cyclosporine-induced immunosuppression. Journal of Ginseng Research; 40(1):18-27.

Ilhan, A.; Iraz, M.; Gurel, A.; Armutcu, F. and Akyol, $O$. (2004): Caffeic acid phenethyl ester exerts a neuroprotective effect on CNS against pentylenetetrazolinduced seizures in mice. 
Neurochemical Research; 29:228792.

Ishida, H.; Miyamoto, N.; Shirakawa, H.; Shimizu, T.; Tokumoto, T.; Ishikawa, N.; Shimmura, H.; Setoguchi, K., Toki, D., Iida, S. and Teraoka, S. (2007): Evaluation of immunosuppressive regimens in ABO-incompatible living kidney transplantation-single center analysis. American journal of transplantation; 7(4):825-831.

Kurus, M.; Esrefoglu, M.; Karabulut, A.B.; Sogutlu, G.; Kaya, M. and Otlu, A. ( 2008): Oral L-arginine protects against cyclosporine-induced

hepatotoxicity in rats. Experimental and Toxicologic Pathology; 60(4): 411-419.

Lee, J. (2010): Use of antioxidants to prevent cyclosporine a toxicity. Toxicological research; 26(3): 163.

Mansour, M.; Daba, M.H.; Gado, A.; Al-Rikabi, A. and Al-Majed, A. (2002): Protective effect of Larginine against nephrotoxicity induced by cyclosporine in normal rats. Pharmacological research; 45(6):441-446.

Park, C.; Yoo, J. H.; Kim, H. J.; Lim, C. Y.;Kim, J. W.;Lee, S. Y. and Park, H. M. (2010): Cyclosporine treatment of perianal gland adenoma concurrent with benign prostatic hyperplasia in a dog. The Canadian Veterinary Journal; 51(11): 1279.

Park, S. W.; Lee, C. H.; Kim, Y. S.; Kang, S. S.; Jeon, S. J.; Son, K. H. and Lee, S. M. (2008): Protective effect of baicalin against carbon tetrachloride-induced acute hepatic injury in mice. Journal of pharmacological sciences; 106(1): 136-143.

Rezzani, R.; Giugno, L.; Buffoli, B.; Bonomini, F. and Bianchi, R. (2005): The protective effect of caffeic acid phenethyl ester against cyclosporine A-induced cardiotoxicity in rats. Toxicology; 212:155- 64.

Rezzani, R.; Rodella, L.F.; Fraschini, F.; Gasco, M.R.; Demartini,G.; Musicanti, C. and Reiter, R. J. (2009): Melatonin delivery insolid lipid nanoparticles: prevention of cyclosporine A induced cardiac damage. Journal of Pineal. Research; 46: 255-261.

Rubert, M.; Montero, M.; Guede, D.; Caeiro, J. R.; Martín-Fernández, M.; Díaz-Curiel, M. and de la Piedra, C. (2015): Sirolimus and tacrolimus rather than cyclosporine A cause bone loss in healthy adult male rats. Bone Reports; 2: 74-81.

Semler, D. (1992): The rat toxicology. In: animal model in toxicology. New York , Basel and Honkong: Marcel Dekker inc. , PP 21-75.

Sovcikova, A.; Tulinska, J.; Kubova, J.; Liskova, A.; Syrova, D. and Horakova, K. (2002): Effect of cyclosporin $\mathrm{A}$ in Lewis rats in vivo and HeLa cells in vitro. Journal of Applied Toxicology; 22(3):153160.

Türk, G.; Ateşşahin, A.; Sönmez, M.; Yüce, A. and Çeribași, A. O. (2007): Lycopene protects against cyclosporine A-induced testicular toxicity in rats.Theriogenology; 67(4): 778785.

Türk, G.; Sönmez, M.; Çeribaşı, A. O.; Yüce, A . and Ateşşahin, A. (2010): Attenuation of cyclosporine A-induced testicular 
and spermatozoal damages associated with oxidative stress by ellagic acid. International immunopharmacology; 10(2): 177182.

Türk, G.; Sönmez, M.; Çeribaşı, A. O.; Yüce, A. and Ateşşahin, A. (2010): Attenuation of cyclosporine A-induced testicular and spermatozoal damages associated with oxidative stress by ellagic acid. International immunopharmacology; 10(2):177182.

Van Thiel, D. H. (1989): Cyclosporine and inflammatory bowel disease.
Digestive diseases and sciences; 34(12): 1817-1819.

Yousef, O.M.H. and ALRajhi, W.I. (2013): The Probable Protective Role of Vitamin $\mathrm{C}$ against Cyclosporine an Induced Pulmonary Changes in Mice. Journal of Life Sciences and Technologies; 1(1):1-6.

Zirkin, B. R. and Chen, H. (2000): Regulation of Leydig cell steroidogenic function during aging. Biology of reproduction; 63(4): 977-981. 


\section{الملخص العربى}

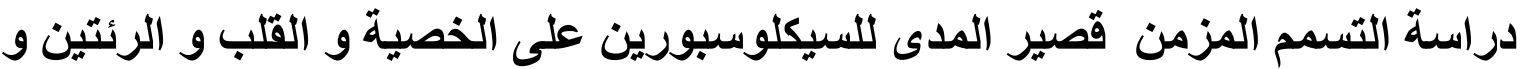

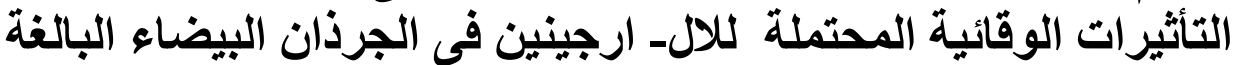

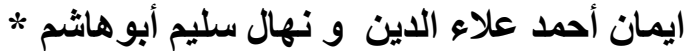

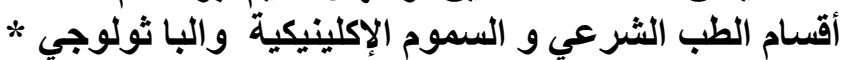 كلية الطب البشري - جامعة الزقازيق البمائي}

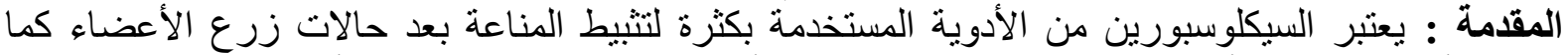

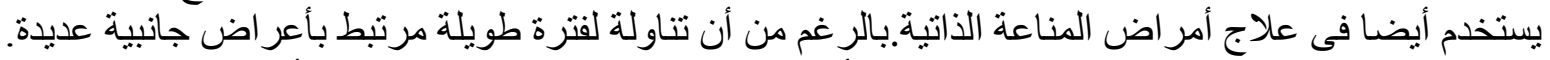

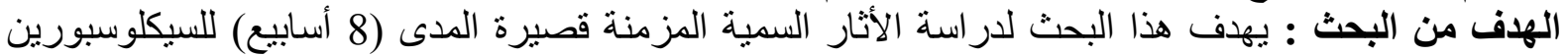

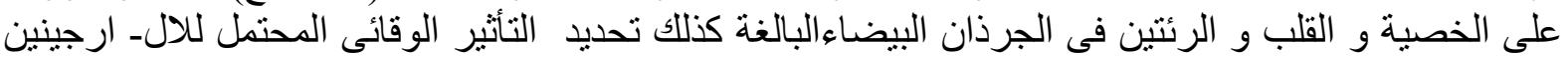
على الاثار السمية للسيكلوسبورين على اللى الأنسجة السابقة.

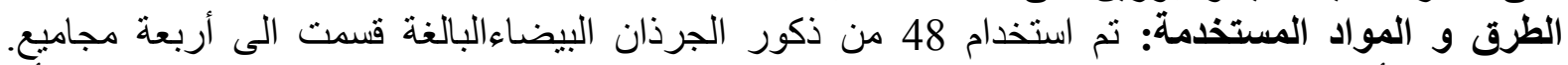

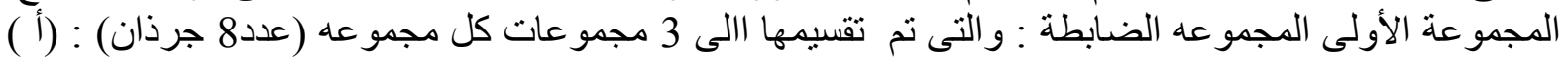

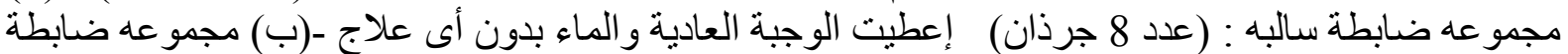

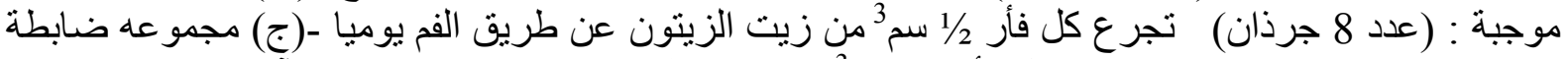

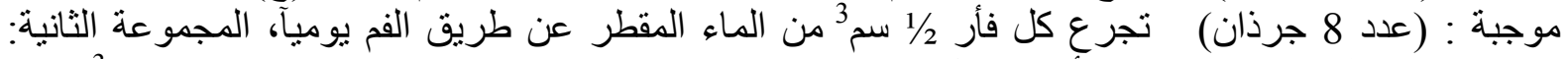

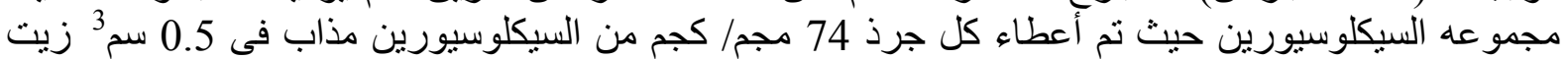

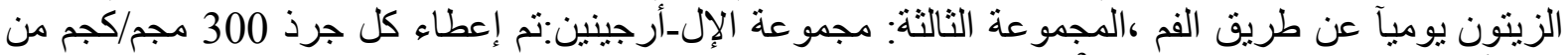

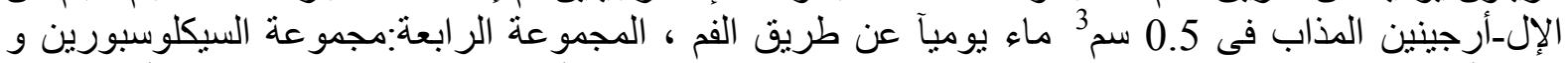

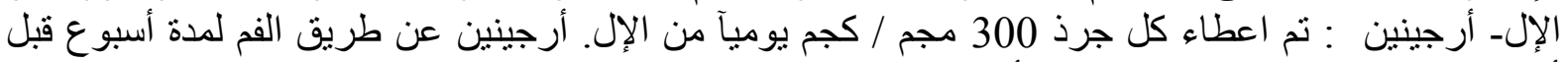

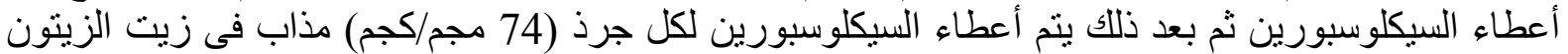

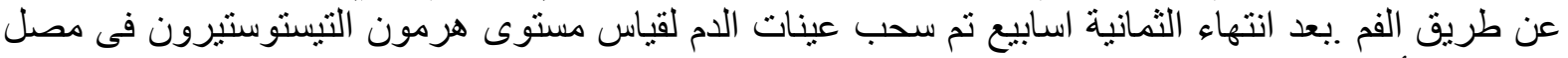

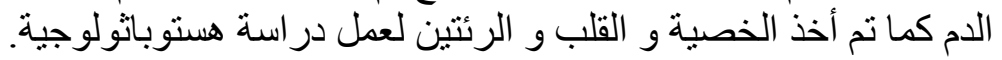

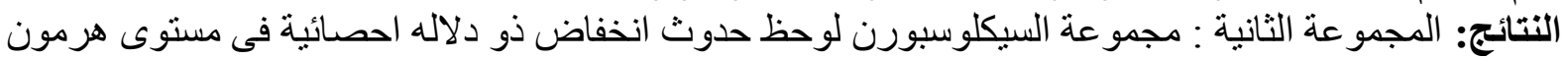

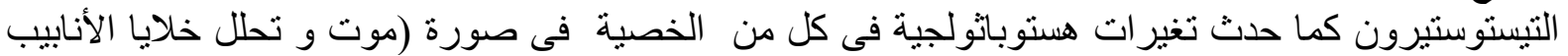

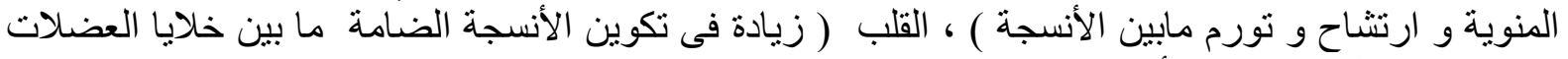

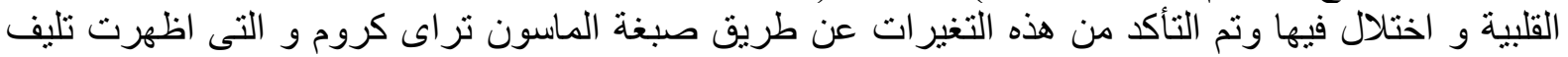

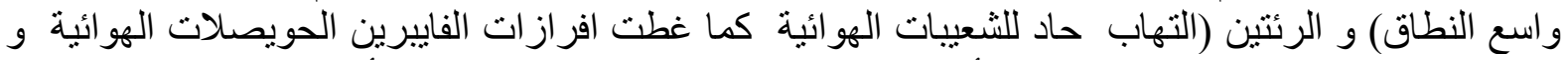

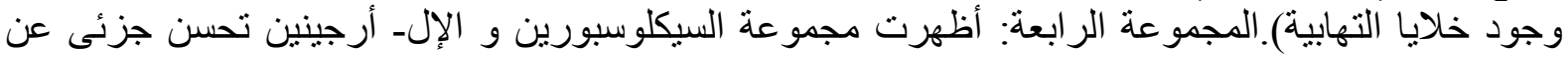

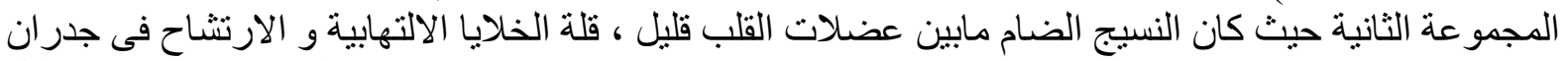

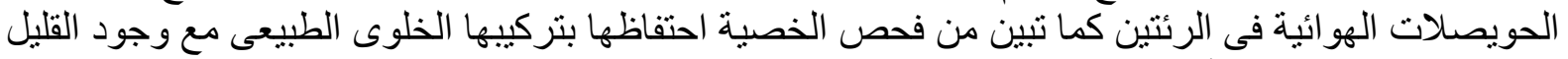

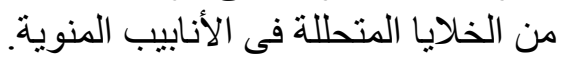

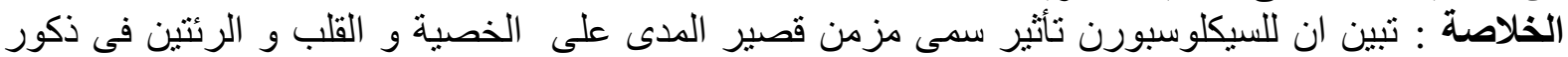
الجرذان البيضاء البالغة و انة بمكن تقليل هذة الأثار السمية بالاستخدام المسبق لالإلإ-أرجينين. 